\title{
The inflammasome and alum-mediated adjuvanticity
}

\author{
Suk-Jo Kang and Richard M Locksley*
}

\author{
Address: Howard Hughes Medical Institute, Departments of Medicine, and Microbiology \& Immunology, University of California San Francisco, \\ 513 Parnassus Avenue, S-1032B, San Francisco, CA 94143-0795, USA \\ *Corresponding author: Richard M Locksley (Locksley@medicine.ucsf.edu) \\ FI000 Biology Reports 2009, I:I5 (doi: 10.3410/BI-15)
}

The electronic version of this article is the complete one and can be found at: http://FI000.com/Reports/Biology/content/I/I5

\begin{abstract}
Recent reports have implicated the NLRP3-associated inflammasome in the adjuvanticity of alum. Here, we summarize the major findings and ask what this may mean for improving human vaccination.
\end{abstract}

\section{Introduction and context}

Since the first report by Glenny et al. [1] that diphtheria toxoid precipitated with aluminum salt generated significantly better immune responses, aluminum-containing adjuvants (alum, aluminum hydroxide) have become the most widely used in human vaccines. Although safe and efficacious, the mechanism of action has remained obscure. Models have shifted from the capacity of adjuvants to establish depots promoting the slow and sustained release of antigen from the injection site, to current hypotheses acknowledging the key role of the innate immune system in providing cytokines and co-stimulatory pathways important for overcoming activation thresholds for adaptive immunity. In this model, adjuvants mimic signals from microbes whose recognition has been hardwired into innate immune recognition structures, as best exemplified by the Tolllike receptors. Alum provokes an antibody response, characterized by a predominance of immunoglobulin G 1 (IgG1) and immunoglobulin E (IgE), that is associated with Th2-mediated immunity [2], however, and host recognition elements associated with such responses remain incompletely defined.

\section{Major recent advances}

Recently, several papers have implicated components of the inflammasome in the adjuvant activity of alum. The inflammasome is a cytosolic intermolecular platform assembled in response to a variety of cellular perturbations and leads to the activation of caspase- 1 from its inactive procaspase form. In turn, active caspase-1 processes the proforms of several interleukin (IL)-1family cytokines, including IL-1 $\beta$, IL-18 and IL-33 [3], and mediates cell death. Each of the reports investigating alum implicate the inflammasome containing NLRP3 (NALP3, cryopyrin, CIAS1), a member of the nucleotidebinding domain-and leucine-rich repeat-containing family of proteins, and an adaptor protein, ASC [apoptosis-associated speck-like protein containing a caspase recruitment domain (CARD)], raising questions of how alum is sensed by the host. Although different approaches and experimental detail preclude complete assessment, several [4-6], but not all [7], of the groups show that the alum-induced IgE and/or IgG1 response requires NLRP3, although all seem to agree that alum induces IL-1 family members through the NLRP3mediated activation of caspase- 1 .

The NLRP3-associated inflammasome can be activated by structurally diverse molecules, including ATP [8-10], gout-associated crystals [monosodium urate (MSU) or calcium pyrophosphate dehydrate] [11], pore-forming toxins (nigericin, maitotoxin, aerolysin, streptolysin $\mathrm{O}$ ) $[8,9,12]$, bacterial RNA, antiviral imidazoquinoline compounds R837 and R848 [13], skin sensitizers $[10,14]$, fibrillar amyloid $\beta$ [15] and particulate molecules, including asbestos, silica and, as recently shown, alum [4-7,16-18]. Confirmation of a few of these effects is lacking, but it still remains an enigma how NLRP3 can recognize such heterogeneous structures. Pore-forming toxins or ATP activation of $\mathrm{P} 2 \mathrm{X} 7$ receptors trigger potassium ion $\left(\mathrm{K}^{+}\right)$efflux from the cell [19]. Conversely, 
Figure I. Alum-induced NLRP3 inflammasome activation

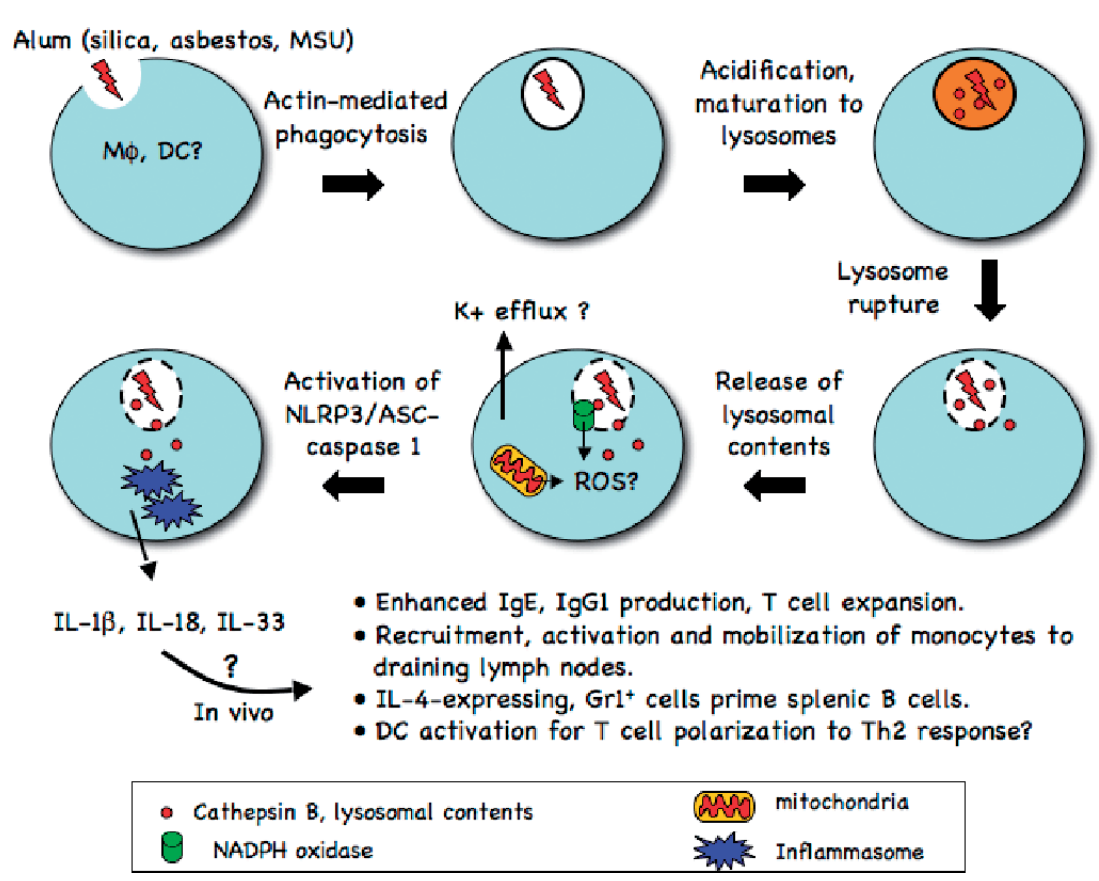

Phagocytosed alum-containing lysosomes rupture and release their components to the cytosol by an unknown mechanism. The released contents and molecules generated during this process contribute to NLRP3/ASC/caspase-I inflammasome activation, which in turn processes the proforms of IL-I family members to active forms. Either IL-I family member cytokines or the products from NLRP3 inflammasome activation may elicit various immunostimulatory effects in vivo. When and how potassium efflux and reactive oxygen species (ROS) play a role awaits further investigation. DC, dendritic cell; MSU,

monosodium urate.

blocking $\mathrm{K}^{+}$depletion inhibits activation of the NLRP3inflammasome by these agents, as well as by crystal-like particulates, including alum $[4,6,12,16,17,20,21]$. Recombinant ASC forms oligomeric complexes at subphysiological $\mathrm{K}^{+}$concentrations, suggesting an important role for $\mathrm{K}^{+}$efflux in promoting inflammasome assembly [21]. The finding that ATP and uric acid crystals released from damaged or dying cells activated the NLRP3 inflammasome raised the possibility that the inflammasome responded to endogenous signals of tissue injury [so-called danger-associated molecular patterns (DAMPs)] as originally proposed by Matzinger [22], rather than to specific microbial ligands [pathogenassociated molecular patterns (PAMPs)] as recognized by the Toll-like receptors. Importantly, however, only the crystalline forms of uric acid (MSU) and alum activate dendritic cells in vitro; the soluble forms are inactive [23]. Uric acid does not appear to be an intermediary during activation of the NLRP3 inflammasome pathway by silica, asbestos or alum, however, since uricase does not block inflammasome activation $[4-6,16,18]$. Thus, the commonality for inflammasome activation by these substances is their physical form as crystals, consistent with the longstanding observation that particulates work as adjuvants.

Recently, Hornung et al. [18] showed that silica, MSU crystals and alum taken up by actin-dependent phagocytosis ultimately cause destabilization of lysosomes, with swelling, increasing $\mathrm{pH}$ and eventual rupture of lysosomal contents into the cytosol. Further, the induction of lysosomal rupture activated the NLRP3 inflammasome, even in the absence of other stimuli. Cathepsin $\mathrm{B}$ released from the lysosome into the cytosol was critical for activation of caspase-1 under these conditions (Figure 1). Cathepsin B has been previously associated with necrosis-like cell death. The pore-forming toxin, nigericin, induces rapid lysosmal leakage and re-location of cathepsin B into the cytosol [24], leading to caspase-1independent, but cathepsin B-dependent, death, called pyronecrosis [25]; blocking cathepsin B activity impaired lysosomal leakage [26]. Moreover, NLRP3 mutations associated with human inflammatory syndromes induce a similar cathepsin B-dependent death pathway $[26,27]$. It is still not clear whether cathepsin B acts upstream or downstream of inflammasome activation, whether cathepsin B is directly sensed or plays a role in generating 
a ligand for NLRP3 or whether its cytosolic localization and induction of pyronecrosis is a necessary step for activation of NLRP3. In addition, reactive oxygen species play a role in ATP or crystal-induced inflammasome activation $[6,16,17]$, but the details of the inter-relationship between $\mathrm{K}^{+}$efflux, reactive oxygen species, lysosomal disruption, and, finally, their physiological significance in generating enhanced antibody responses remain unknown. Finally, the mechanism by which particulates result in lysosomal destabilization remains unclear, although the possibility exists that physical rupture of the membrane due to the irregularities of the crystalline substances is itself the common underlying pathway.

\section{Future directions}

An important question is whether the IL-1 family cytokines generated by the alum-activated NLRP3 inflammasome are critical for isotype switching to IgG1 and IgE. Alum induces neutrophil-rich granulomas at the injection site [28]. When injected into the peritoneum or trachea, alum or silica elicited neutrophil and monocyte recruitment by an IL-1/IL-1 receptor/MyD88 pathway $[18,29]$. Monocytes recruited by alum process co-injected antigens, mature, migrate to the draining lymph nodes and expand antigen-specific $\mathrm{T}$ cells through a process in part dependent on NLRP3 $[6,29]$. Whether these monocytes are required for enhanced antibody responses remains unanswered. Although IL-1 has been shown to increase antigen-specific T cells [30], IL-1R1-deficient mice generated normal antigen-specific antibody responses following intraperitoneal immunization in models using trinitrophenol-keyhole limpet hemocyanin and asthma [31,32]. IL-18 can increase IgE production and Th2 cytokines [33,34], but IgG1 and IgE production was not affected by IL-18 deficiency [35]. IL-33 stimulates production of IL-4, IL-5 and IL-13 [36]. However, deletion of the IL-33 receptor, T1/ST2, did not impair the alum-induced asthma response [37]. The lack of defects in the individual knockout mice may be due to redundant functions among IL-1 family members. All three of these IL-1 family members share MyD88 for signaling [38], however, and IgG1 production was normal in MyD88-deficient mice immunized with ovalbumin and alum $[4,39]$ and no defect in antibody production was seen using mice genetically deficient in

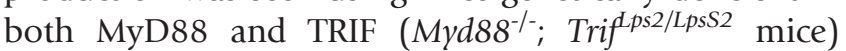
challenged with trinitrophenol-hemocyanin [40]. Therefore, until the possibility of a MyD88-independent signaling pathway is shown, the involvement of IL-1 family members in the alum response remains inconclusive.
Most of the in vitro experiments in these various reports used macrophages and/or human monocytic cell lines. Since dendritic cells (DCs) play a critical role in T cell activation and differentiation, an important question remains whether alum programs DCs to enhance a Th2mediated immune response through activation of the NLRP3 inflammasome. Alum induced in vitro DC differentiation, as measured by upregulation of costimulatory molecules, in one [41], but not other studies [23,42]. Alum generated uric acid in vivo [29], which could lead to crystalline MSU particles able to induce DC maturation. Indeed, the alum-induced recruitment of monocytes to the draining lymph nodes was abrogated by uricase treatment [29]. DC activation may be regulated at the level of caspase- 1 or ASC, and not by IL-1 family members. Caspase- 1 has been shown to cleave many substrates that can regulate cell survival and tissue repair [43]. Toxin-mediated $\mathrm{K}^{+}$depletion induces sterol regulatory element binding protein (SREBP) activation via caspase-1, potentially leading to activation of membrane repair pathways [12]. It is also possible that alum facilitates Th2-associated immune responses independent of DCs. Alum recruits IL-4-expressing $\mathrm{Gr}^{+}$ cells to the spleen where these cells could prime B cells [44-46] and suppress Th1-associated antibody responses [46]. Further study of the alum (or crystal)-induced inflammasome may provide insights into the integration of signals by the inflammasome and the molecular pathways that trigger Th2-associated immune responses, even beyond the antibody-enhancing effects of adjuvants, and greatly improve our capacity to design rational vaccine adjuvants for use in humans as well.

\section{Abbreviations}

ASC, apoptosis-associated speck-like protein containing a caspase recruitment domain (CARD); DC, dendritic cell; IgG1, immunoglobulin G1; IgE, immunoglobulin E; $\mathrm{IL}$, interleukin; MSU, monosodium urate.

\section{Competing interests}

The authors declare that they have no competing interests.

\section{References}

I. Glenny AT, Pope CG, Waddington H, Wallace U: Immunological notes XVII - XXIV. J Pathol Bacteriol I926, 29:3 I-40.

2. Brewer JM: (How) do aluminium adjuvants work? Immunol Lett 2006, I02:10-5.

3. Mariathasan S, Monack DM: Inflammasome adaptors and sensors: intracellular regulators of infection and inflammation. Nat Rev Immunol 2007, 7:31-40.

4. Eisenbarth SC, Colegio OR, O'Connor W, Sutterwala FS, Flavell RA: Crucial role for the Nalp3 inflammasome in the 
immunostimulatory properties of aluminium adjuvants. Nature 2008, 453: I |22-6.

FI000 Factor 6.6 Must Read

Evaluated by Drusilla Burns 28 May 2008, David Chaplin I 4 Jul 2008

Dale Umetsu 28 Jul 2008, Shizuo Akira 9 Sep 2008

5. Li H, Willingham SB, Ting JP, Re F: Cutting edge: inflammasome activation by alum and alum's adjuvant effect are mediated by NLRP3. J Immunol 2008, I8I:I7-2I.

FI000 Factor 6.0 Must Read

Evaluated by Denise M Monack 23 Jul 2008

6. Kool M, Petrilli V, De Smedt T, Rolaz A, Hammad H, van Nimwegen M, Bergen IM, Castillo R, Lambrecht BN, Tschopp J: Cutting Edge: alum adjuvant stimulates inflammatory dendritic cells through activation of the NALP3 inflammasome. J Immunol 2008, 181:3755-9.

7. Franchi L, Nunez G: The NIrp3 inflammasome is critical for aluminium hydroxide-mediated IL-Ibeta secretion but dispensable for adjuvant activity. Eur J Immunol 2008, 38:2085-9.

FI000 Factor 3.0 Recommended

Evaluated by Moriya Tsuji 3 Sep 2008

8. Mariathasan S, Weiss DS, Newton K, McBride J, O'Rourke K, RooseGirma M, Lee WP, Weinrauch Y, Monack DM, Dixit VM: Cryopyrin activates the inflammasome in response to toxins and ATP. Nature 2006, 440:228-32.

FI000 Factor 6.0 Must Read

Evaluated by Astar Winoto 17 Mar 2006

9. Kanneganti TD, Lamkanfi M, Kim YG, Chen G, Park JH, Franchi L, Vandenabeele $\mathrm{P}$, Nunez G: Pannexin-I-mediated recognition of bacterial molecules activates the cryopyrin inflammasome independent of Toll-like receptor signaling. Immunity 2007, 26:433-43.

10. Sutterwala FS, Ogura Y, Szczepanik M, Lara-Tejero M, Lichtenberger GS, Grant EP, Bertin J, Coyle AJ, Galán JE, Askenase PW, Flavell RA: Critical role for NALP3/CIASI/Cryopyrin in innate and adaptive immunity through its regulation of caspase-I. Immunity 2006, 24:317-27.

FI000 Factor 6.0 Must Read

Evaluated by Astar Winoto 24 Mar 2006

II. Martinon F, Petrilli V, Mayor A, Tardivel A, Tschopp J: Goutassociated uric acid crystals activate the NALP3 inflammasome. Nature 2006, 440:237-41.

FI000 Factor 9.7 Exceptional

Evaluated by Marina Botto 30 Jan 2006, Richard Pope 17 Mar 2006, Robert Terkeltaub 28 Mar 2006

12. Gurcel L, Abrami L, Girardin S, Tschopp J, van der Goot FG: Caspase-I activation of lipid metabolic pathways in response to bacterial pore-forming toxins promotes cell survival. Cell 2006, I 26: I | 35-45

FI000 Factor 4.8 Must Read

Evaluated by Grant McFadden 6 Oct 2006, Robert Parton 2 Nov 2006

13. Kanneganti TD, Ozören N, Body-Malapel M, Amer A, Park JH, Franchi L, Whitfield J, Barchet W, Colonna M, Vandenabeele P, Bertin J, Coyle A, Grant EP, Akira S, Núñez G: Bacterial RNA and small antiviral compounds activate caspase-I through cryopyrin/Nalp3. Nature 2006, 440:233-6.

FI000 Factor 3.0 Recommended

Evaluated by Bryan Williams 8 May 2006

14. Watanabe H, Gaide O, Petrilli V, Martinon F, Contassot E, Roques S, Kummer JA, Tschopp J, French LE: Activation of the IL-Ibetaprocessing inflammasome is involved in contact hypersensitivity. J Invest Dermatol 2007, I27:1956-63.
15. Halle A, Hornung V, Petzold GC, Stewart CR, Monks BG, Reinheckel T, Fitzgerald KA, Latz E, Moore KJ, Golenbock DT: The NALP3 inflammasome is involved in the innate immune response to amyloid-beta. Nat Immunol 2008, 9:857-65.

FI000 Factor 6.4 Must Read

Evaluated by Xiaojing Ma 30 Jul 2008, Sergio Grinstein with Gregory Fairn 7 Aug 2008

16. Dostert C, Petrilli V, Van Bruggen R, Steele C, Mossman BT, Tschopp J: Innate immune activation through Nalp3 inflammasome sensing of asbestos and silica. Science 2008, 320:674-7.

FI000 Factor 6.5 Must Read

Evaluated by David Underhill 25 Apr 2008, Bruce Pitt 25 Apr 2008, Christoph Borner 27 May 2008

17. Cassel SL, Eisenbarth SC, lyer SS, Sadler J], Colegio OR, Tephly LA Carter AB, Rothman PB, Flavell RA, Sutterwala FS: The Nalp3 inflammasome is essential for the development of silicosis. Proc Natl Acad Sci U S A 2008, 105:9035-40.

18. Hornung V, Bauernfeind F, Halle A, Samstad EO, Kono H, Rock KL, Fitzgerald KA, Latz E: Silica crystals and aluminum salts activate the NALP3 inflammasome through phagosomal destabilization. Nat Immunol 2008, 9:847-56.

FI000 Factor 3.0 Recommended

Evaluated by David Underhill 29 Jul 2008

19. Perregaux D, Gabel CA: Interleukin-I beta maturation and release in response to ATP and nigericin. Evidence that potassium depletion mediated by these agents is a necessary and common feature of their activity. I Biol Chem 1994, 269: $15195-203$.

20. Petrilli V, Papin S, Dostert C, Mayor A, Martinon F, Tschopp J: Activation of the NALP3 inflammasome is triggered by low intracellular potassium concentration. Cell Death Differ 2007, 14:1583-9.

21. Fernandes-Alnemri T, Wu J, Yu JW, Datta P, Miller B, Jankowski W, Rosenberg S, Zhang J, Alnemri ES: The pyroptosome: a supramolecular assembly of ASC dimers mediating inflammatory cell death via caspase-I activation. Cell Death Differ 2007, I4:1590-604.

22. Matzinger P: Tolerance, danger, and the extended family. Annu Rev Immunol 1994, I 2:991-1045.

23. Shi Y, Evans JE, Rock KL: Molecular identification of a danger signal that alerts the immune system to dying cells. Nature 2003, 425:516-21.

FI000 Factor II.0 Exceptional

Evaluated by Caetano Reis e Sousa 8 Oct 2003, Allan Zajac 9 Oct 2003, Jonathan Gleadle 10 Oct 2003, Michael Gold I5 Oct 2003, Michael McHeyzer-Williams 20 Oct 2003, David Branch Moody 23 Oct 2003, Stefan Kaufmann 29 Oct 2003, Matthias von Herrath 3 Nov 2003, Luis J Montaner 26 Nov 2003, Richard Vile I5 Jan 2004

24. Hentze H, Lin XY, Choi MS, Porter AG: Critical role for cathepsin $B$ in mediating caspase-I-dependent interleukin- 18 maturation and caspase-I-independent necrosis triggered by the microbial toxin nigericin. Cell Death Differ 2003, 10:956-68.

25. Ting JP, Willingham SB, Bergstralh DT: NLRs at the intersection of cell death and immunity. Nat Rev Immunol 2008, 8:372-9.

26. Fujisawa A, Kambe N, Saito M, Nishikomori R, Tanizaki H, Kanazawa N, Adachi S, Heike T, Sagara J, Suda T, Nakahata T, Miyachi Y: Disease-associated mutations in CIASI induce cathepsin Bdependent rapid cell death of human THP-I monocytic cells. Blood 2007, 109:2903-II.

27. Willingham SB, Bergstralh DT, O'Connor W, Morrison AC, Taxman DJ, Duncan JA, Barnoy S, Venkatesan MM, Flavell RA, Deshmukh M, Hoffman HM, Ting JP: Microbial pathogen-induced necrotic cell death mediated by the inflammasome components CIASI/ cryopyrin/NLRP3 and ASC. Cell Host Microbe 2007, 2:147-59.

28. White RG, Coons $\mathrm{AH}$, Connolly JM: Studies on antibody production III. The alum granuloma. J Exp Med 1955, 1 02:73-82. 
29. Kool M, Soullie T, van Nimwegen M, Willart MA, Muskens F, Jung S, Hoogsteden HC, Hammad H, Lambrecht BN: Alum adjuvant boosts adaptive immunity by inducing uric acid and activating inflammatory dendritic cells. J Exp Med 2008, 205:869-82.

FI000 Factor 6.0 Must Read

Evaluated by Eric Denkers 28 Mar 2008

30. Pape KA, Khoruts A, Mondino A, Jenkins MK: Inflammatory cytokines enhance the in vivo clonal expansion and differentiation of antigen-activated CD4+ T cells. J Immunol I997, I 59:59|-8.

3I. Glaccum MB, Stocking KL, Charrier K, Smith JL, Willis CR, Maliszewski C, Livingston DJ, Peschon JJ, Morrissey PJ: Phenotypic and functional characterization of mice that lack the type I receptor for IL-I. J Immunol I997, I 59:3364-7I.

32. Schmitz N, Kurrer M, Kopf M: The IL-I receptor I is critical for Th2 cell type airway immune responses in a mild but not in a more severe asthma model. Eur J Immunol 2003, 33:991-1000.

33. Yoshimoto $T$, Mizutani $H$, Tsutsui H, Noben-Trauth $N$, Yamanaka $K$, Tanaka M, Izumi S, Okamura H, Paul WE, Nakanishi K: IL-I8 induction of IgE: dependence on CD4+ T cells, IL-4 and STAT6. Nat Immunol 2000, I:I32-7.

34. Hoshino $T$, Yagita $H$, Ortaldo JR, Wiltrout $R H$, Young $H A$ : In vivo administration of IL-I 8 can induce IgE production through Th2 cytokine induction and up-regulation of CD40 ligand (CDI54) expression on CD4+ $\mathbf{T}$ cells. Eur J Immunol 2000, 30:1998-2006.

35. Pollock KG, Conacher M, Wei XQ, Alexander J, Brewer JM: Interleukin- 18 plays a role in both the alum-induced $T$ helper 2 response and the $T$ helper I response induced by alumadsorbed interleukin-12. Immunology 2003, I 08:137-43.

36. Schmitz J, Owyang A, Oldham E, Song Y, Murphy E, McClanahan TK, Zurawski G, Moshrefi M, Qin J, Li X, Gorman DM, Bazan JF, Kastelein RA: IL-33, an interleukin-I-like cytokine that signals via the IL-I receptor-related protein ST2 and induces T helper type 2-associated cytokines. Immunity 2005, 23:479-90.

FI000 Factor 6.0 Must Read

Evaluated by Richard Grencis 4 Jan 2006

37. Hoshino K, Kashiwamura S, Kuribayashi K, Kodama T, Tsujimura T, Nakanishi K, Matsuyama T, Takeda K, Akira S: The absence of interleukin I receptor-related TI/ST2 does not affect T helper cell type $\mathbf{2}$ development and its effector function. $J$ Exp Med 1999, 190:1541-8.

38. Arend WP, Palmer G, Gabay C: IL-I, IL-I 8, and IL-33 families of cytokines. Immunol Rev 2008, 223:20-38.
39. Schnare M, Barton GM, Holt AC, Takeda K, Akira S, Medzhitov R: Toll-like receptors control activation of adaptive immune responses. Nat Immunol 200 I, 2:947-50.

FI000 Factor 4.9 Must Read

Evaluated by Bruno Lemaitre 23 Nov 200I, Luigina Romani 27 Nov 200I, Jean-Marc Reichhart 2 Jan 2002

40. Gavin AL, Hoebe K, Duong B, Ota T, Martin C, Beutler B, Nemazee $D$ : Adjuvant-enhanced antibody responses in the absence of toll-like receptor signaling. Science 2006, 3 I 4: 1936-8.

FI000 Factor 6.6 Must Read

Evaluated by Emanuela Handman 15 Jan 2007, Gary Bokoch 18 Jan 2007, Jenny Ting 28 Feb 2007

41. Sokolovska A, Hem SL, HogenEsch H: Activation of dendritic cells and induction of CD4(+) $\mathrm{T}$ cell differentiation by aluminumcontaining adjuvants. Vaccine 2007, 25:4575-85.

42. Sun H, Pollock KG, Brewer JM: Analysis of the role of vaccine adjuvants in modulating dendritic cell activation and antigen presentation in vitro. Vaccine 2003, $21: 849-55$.

43. Keller M, Ruegg A, Werner S, Beer HD: Active caspase-I is a regulator of unconventional protein secretion. Cell 2008, |32:8|8-3|.

FI000 Factor 6.6 Must Read

Evaluated by Vishvanath Nene 10 Apr 2008, Ivor Mason 8 May 2008, Moosa Mohammadi 29 May 2008, Jenny Ting 4 Aug 2008

44. Jordan MB, Mills DM, Kappler J, Marrack P, Cambier JC: Promotion of $B$ cell immune responses via an alum-induced myeloid cell population. Science 2004, 304: I808-10.

FI000 Factor 4.8 Must Read

Evaluated by Richard Locksley I Jul 2004, Dan Conrad I2 Jul 2004

45. Wang HB, Weller PF: Pivotal advance: eosinophils mediate early alum adjuvant-elicited $B$ cell priming and IgM production. J Leukoc Biol 2008, 83:817-2I.

FI000 Factor 3.2 Recommended

Evaluated by Helene Rosenberg 6 Feb 2008, Charles Czuprynski I Apr 2008

46. McKee AS, MacLeod M, White J, Crawford F, Kappler JW, Marrack P: GrI+IL-4-producing innate cells are induced in response to Th2 stimuli and suppress Th I-dependent antibody responses. Int Immunol 2008, 20:659-69. 